\title{
Eccentricity dimension of the Dimensional Clinical Personality Inventory: Review and psychometric properties
}

Lucas de Francisco Carvalho. Universidade São Francisco.

Giselle Pianowski. Universidade São Francisco.

Fernando José Silveira. Universidade do Vale do Sapucaí.

Jonatha Tiago Bacciotti. Universidade São Francisco.

Philipe Gomes Vieira. Instituto de Pós-Graduação de Goiás.

\begin{abstract}
We aimed to review of the Eccentricity dimension of the Dimensional Clinical Personality Inventory (IDCP), through two steps. The first one focused on developing new items and the second on testing the psychometric properties in a sample of 225 subjects (70.1\% females), aging between 18 and 66 years, mostly undergraduate students (58.9\%). The subjects answered the IDCP, and the Brazilian versions of the NEO-PI-R, PID-5 and MIS. The first step resulted in 42 items, which 22 were new. The second step resulted in a composite of 18 items, pooled in six interpretable factors, as Interpersonal detachment, Eccentric style, Paranormality, Persecutory style, Depersonalization and Emotional inexpressiveness, with internal consistency coefficients of .85 for the total score, and between .60 and .82 for the factors. The correlations between instruments revealed consistent and expected relations. The data suggested adequacy of the new Eccentricity dimension of IDCP.
\end{abstract}

Keywords: personality traits; psychological testing; personality disorders.

\section{Resumo}

Dimensão Excentricidade do Inventário Dimensional Clínico da Personalidade: Revisão e propriedades psicométricas. O objetivo do estudo foi revisar a dimensão Excentricidade do Inventário Dimensional Clínico da Personalidade (IDCP), em duas etapas. A primeira etapa focada no desenvolvimento de novos itens e a segunda na verificação das propriedades psicométricas em uma amostra de 225 indivíduos (70,1\% do sexo feminino), com idades entre 18 e 66 anos, em sua maioria estudantes de graduação (58,9\%). Os participantes responderam ao IDCP, e às versões brasileiras do NEO-PI-R, PID-5 e MIS. A primeira etapa resultou em 42 itens, sendo 22 novos. A segunda etapa resultou em um conjunto de 18 itens, agrupados em seis fatores interpretáveis, Distanciamento Interpessoal, Estilo Excêntrico, Paranormalidade, Estilo Persecutório, Despersonalização e Inexpressividade Emocional, com coeficientes de consistência interna de 0,85 para o escore total e entre 0,60 e 0,82 para os fatores. As correlações entre os instrumentos revelaram-se consistentes e esperadas. Os dados demonstraram adequação da nova dimensão Excentricidade do IDCP.

Palavras-chave: traços de personalidade; testes psicológicos; distúrbios da personalidade.

\section{Resumen}

Dimensión Excentricidad del Inventario Dimensional Clínico de la Personalidad: Revisión y psicométricas propiedades. El estudio tuvo como objetivo revisar la dimensión Excentricidad del Inventario Dimensional Clínico de la Personalidad (IDCP), en dos pasos. Uno para el desarrollo de nuevos ítems y otro para probar las propiedades psicométricas en una muestra de 225 sujetos (70,1\% mujeres), con edades entre 18 y 66 años, estudiantes universitarios en su mayoría (58,9\%). Los sujetos respondieron el IDCP, y las versiones brasileñas del NEO-PI-R, PID-5 y MIS. El primer paso resultó en 42 ítems, los cuales 22 eran nuevos. El segundo, dio lugar a una mezcla compuesta de 18 ítems, agrupados en seis factores interpretables, Desapego interpersonal, Estilo excéntrico, Paranormalidad, Estilo persecutorio, Despersonalización y Inexpresividad emocional, con coeficientes de consistencia interna de 0,85 para el total, y entre 0,60 y 0,82 para los factores. Las correlaciones entre los instrumentos revelaron relaciones consistentes y esperadas. Los datos demuestran la idoneidad de la nueva dimensión Excentricidad del IDCP.

Palabras clave: rasgos de personalidad; tests psicológicos; trastornos de la personalidad. 
The scarcity of publications addressing psychiatric disorders according to the Diagnostic and Statistical Manual for Mental Disorders (DSM-5) (American Psychiatry Association [APA], 2013a) is notable in Brazil. An example of that is the limited number of psychological instruments approved by the Evaluation System of Psychological Tests (SATEPSI) for the assessment of pathological functioning considering the diagnostic categories presented in DSM-5. Specifically, regarding the assessment of diagnostic criteria that give base to personality disorders, such compliance to the DSM-5 proposal seems not considered in the previously available instruments for professional use in the Brazilian context. This limitation can compromise the national clinical practice and the Brazilian participation on international exchange of researches in personality assessment.

The national shortage of tests assessing pathological personality traits based on the scientific advances included in section 3 of the DSM- 5 was one of the main elicitors to research implementation with the goal of revising the dimensions composing the Dimensional Clinical Personality Inventory (IDCP) (Carvalho \& Primi, 2015). The IDCP consists of an assessment instrument with twelve dimensions measuring personality traits in pathological levels (Dependency, Aggressiveness, Mood Instability, Eccentricity, Attention Seeking, Distrust, Grandiosity, Isolation, Criticism Avoidance, Self-sacrifice, Conscientiousness and Impulsiveness) developed based on the DSM-IV-TR diagnostic criteria (APA, 2003b) and the pathological personality characteristics present in the theory of Theodore Millon (Millon, Grossman, \& Tringone, 2010; Millon, Millon, Meagher, Grossman, \& Ramnath, 2004).

The IDCP is relevant for identifying personality pathological functioning and to establish individual's profiles (Abela, Carvalho, Cho, \& Yazigi, 2015; Carvalho $\&$ Primi, 2015, 2016), therefore, its dimensions has been the focus of investments seeking for improvements, mainly in the representativeness of the construct of each dimension, their psychometric properties and clinical functioning. Most of the IDCP's dimensions have been revised, as, Dependency (Carvalho \& Pianowski, 2015), Aggressiveness (Carvalho, Pianowski, \& Miguel, 2015), Mood Instability (Carvalho \& Sette, 2015), Attention Seeking (Carvalho, Sette, \& Capitão, 2016; Carvalho, Sette, Capitão, \& Primi, 2014), Grandiosity (Carvalho, Sette, \& Ferrari, 2016), Isolation (Carvalho \& Arruda, 2016), Criticism Avoidance (Carvalho \& Sette, in press), Self-sacrifice (Carvalho \& Silva, 2016) and
Conscientiousness (Carvalho, Souza, \& Primi, 2014a, 2014b). The present study frames within that scope, focusing on the Eccentricity dimension of IDCP.

Eccentricity corresponds to 20 of the 163 items of the IDCP (Carvalho \& Primi, 2015), presenting content related to eccentric behaviour, interpersonal maladjustment associated to distrust others and lack of social pleasure, also linked with a belief in being different from others. The psychometrics analyses demonstrated adequate reliability coefficient for this dimension $(a=.92)$ and for each dimension of IDCP, as well as validity evidence based on internal structure, by exploratory and confirmatory factor analysis, and rating scale model from IRT's Rasch model (Carvalho \& Primi, 2015; Carvalho, Primi, \& Stone, 2014); and based on external variables, as psychiatric diagnosis and psychological tests (Abela et al., 2015; Carvalho, Oliveira-Filho, Pessotto, \& Bortoli, 2014; Carvalho \& Primi, 2015, 2016).

The Eccentricity dimension revealed correlation with the schizotypal, schizoid (Abela et al., 2015; Carvalho \& Primi, 2015) and paranoid personality disorders (Carvalho \& Primi, 2016). The schizotypal disorder corresponds to a functioning with social deficits marked by discomfort in interpersonal relationships, cognitive and perceptual distortions and behavioural eccentricities; the schizoid is associated to a pervasive pattern of detachment in social relations and restrictions on emotional expression in interpersonal relationships; and the paranoid functioning exposes a durable pattern of distrust in interpersonal relationships, pervaded by suspicion of intent to others and emotional liability (APA, 2013).

The literature has shown similar relations of the eccentricity characteristics with these disorders, especially schizotypal. The research of Samuel, Lynam, Widiger and Ball (2012) presented an accordance between judges, specialists in pathological manifestation of personality, with the scales from Personality Inventory for DSM-5 (PID- 5). Some dimensions were categorized as extremely descriptive for the schizotypal personality disorder, namely, Unusual beliefs, Unusual perceptions, Eccentricity, Cognitive dysregulation, Social withdrawal and Suspiciousness; moderately descriptive, as Social detachment, Intimacy avoidance and Dissociation proneness; and little descriptive, as Restricted affectivity and Anxiousness. In the same direction, the study of Hopwood, Thomas, Markon, Krueger and Wright (2012) showed correlations of the schizoid functioning with 
PID-5 dimensions, namely, Withdrawal, Anhedonia, Intimacy avoidance and Restricted Affectivity.

The present research was conducted considering these evidences as a support of the relevancy of the items set of the IDCP's Eccentricity dimension to pathological personality traits assessment, mainly those related to schizotypal personality disorders. Despite those evidences, as already discussed, the section 3 from DSM-5 as well other relevant references in the field, presents information related to each personality disorder that must be considerate in the assessment tools of personality pathology. This study aimed to review the Eccentricity dimension of IDCP, through the development of new items based on prominent literature, and by testing the psychometric properties of the revised version. Still, we sought to investigate the possibility of establishing profiles based on the reviewed dimension factors.

\section{Method}

The review of the Eccentricity dimension was performed in two steps. The Step 1 was directed to the development of new items and the Step 2 intended for testing the psychometric properties of the revised version.

\section{Step 1}

\section{Procedures}

For the development of new items for the Eccentricity dimension, we verified the literature considered relevant in the pathological personality field, intended to understand the pathological manifestations of the underlying construct of the dimension, replicating previously procedures (Carvalho \& Arruda, 2016; Carvalho \& Pianowski, 2015; Carvalho et al., 2015; Carvalho \& Sette, 2015; Carvalho \& Sette, in press; Carvalho, Sette, \& Ferrari, 2016; Carvalho, Sette, Capitão et al., 2014; Carvalho \& Silva, 2016; Carvalho, Souza et al., 2014a, 2014b). We consult the Section 3 of the DSM-5 (APA, 2013a), the facets of the Personality Inventory for DSM-5 (PID-5) (Krueger, Derringer, Markon, Watson, \& Skodol, 2012), the dimensions of the Shedler-Westen Assessment Procedure (SWAP-200) (Shedler \& Westen, 2004) and the model of Clark (1990) that supports the Schedule for Nonadaptive Personality (SNAP).

The literature was analyzed by two judges, authors of this study, who sought to cast the constructs and characteristics related to the eccentric functioning, focusing on the scope and representativeness of Eccentricity dimension. We selected sentences and included in a spreadsheet maintaining the original language (i.e., English), which was followed by independent translation and consensus of three judges (authors of this study). For selection of the sentences, the judges considered, primarily, the presence of relevant contents to the underlying latent construct and related to the schizotypal personality disorder.

Based on the selected sentences, the five authors of this study developed new items, independently. For each sentence, the researchers created one or two items, which generated between five and ten new items for each sentence. After the creation of items, we made a pre-selection, trying to identify the items with most adequate content. The final composite of items to be tested was generated by consensus among the researchers, focusing on representativeness of the characteristics, pathological levels of the construct, clarity in writing and no redundancy of content.

\section{Step 2}

\section{Participants}

225 participants, aging between 18 and 66 years ( $M=26.2, S D=8.1), 162$ females $(70.1 \%)$, and majority of undergraduate students (58.9\%), accessed by convenience. Were identified participants with a history of psychiatric/psychological treatment, of which 68 reported having undergone psychotherapeutic process, 12 have made psychiatric treatment and 11 reported use of psychotropic medication.

\section{Instruments}

For this study, four instruments were applied, the Dimensional Clinical Personality Inventory (IDCP) (Carvalho \& Primi, 2015), the Brazilian version of the NEO Personality Inventory Revised (NEO-PI-R) (Costa Jr. $\&$ McCrae, 2009), the Brazilian version of the Personality Inventory for DSM-5 (PID-5) (Krueger et al., 2012), and the Brazilian version of the Magical Ideation Scale (MIS) (Eckblad \& Chapman, 1983).

The IDCP is an instrument developed for the assessment of pathological personality traits based on the theory of Millon (Millon \& Grossman, 2007a, 2007b; Millon et al., 2004) and diagnostic criteria of axis II of the DSM-IV (APA, 2003b). Originally the instrument comprises 163 items on a Likert 4-point scale, where " 1 " stands for "has nothing to do with me" and "4" for "everything to do with me", with an average time 
to complete of 25 minutes. The items cover the 12 dimensions of the IDCP, Dependency, Aggressiveness, Mood Instability, Eccentricity, Attention Seeking, Distrust, Grandiosity, Isolation, Criticism Avoidance, Self-sacrifice, Conscientiousness and Impulsiveness. Studies have shown the adequacy of the psychometric properties of the IDCP dimensions (Abela et al., 2015; Carvalho, Oliveira-Filho et al., 2014; Carvalho \& Primi, 2015, 2016; Carvalho, Primi, \& Stone, 2014), including validity evidence based on internal structure (Classical Test Theory and Item Response Theory) and on the relation to external variables (NEO-PI-R and psychiatric diagnosis), and reliability coefficients for internal consistency.

The NEO-PI-R is a self-report inventory focused on the evaluation of adult personality composed of 240 items on a Likert scale of 5 points, ranging from 1 (strongly disagree) to 5 (strongly agree), with applying time of approximately 25 minutes. The instrument covers five dimensions of personality, Neuroticism, Extraversion, Openness, Agreeableness and Conscientiousness, however, for this study we considered the Neuroticism and Agreeableness dimensions, considering the reviewed dimension in the present study. The manual of the Brazilian version presents studies demonstrating evidence of validity and satisfactory reliability indices (Costa Jr. \& McCrae, 2009).

The PID-5 is a self-report inventory developed for assessing the pathological characteristics of personality contained in criterion $B$ of personality disorders presented in the section 3 of DSM-5 (APA, 2013a). It consists of 220 items that should be answered on a Likert 4-point scale, with 0 equal to "false or often false" and 3 equal to "true or often true". The PID- 5 is represented by 25 facets, grouped into five dimensions, Negative Affect, Detachment, Antagonism, Disinhibition and Psychoticism, for this study, however, was used strictly Callousness, Eccentricity, Avoidance of Intimacy, Perceptual dysregulation and Unusual Beliefs and Experiences facets. No national studies were found checking the psychometric properties of the Brazilian version, but Krueger et al. (2012) presented data that indicate the suitability of the original version of the test.

Finally, MIS is also a self-report scale that assesses magical thinking, consisting of 30 items on a dichotomous scale of true and false type. The proposed items are compatible to schizophrenia spectrum disorders symptoms. The score corresponds to assigning 1 point for each time the indicated category (true or false) corresponds to the expected presence of magical thinking in accordance with the model proposed by Eckbard and Chapman (1983). The cut-off points proposed by the authors are 19 for men and 20 for women. MIS has shown evidence of validity in differentiating clinical groups (Chapman, Chapman, Kwapil, Eckblad, \& Zinser, 1994; Eckblad \& Chapman, 1983). The Brazilian version was adapted by Vieira, Villemor-Amaral and Pianowski (in press).

\section{Procedures}

After submission and approval of the Research Ethics Committee (CAAE: 21992113.1.0000.5514), the data collection was started in a particular university of an up-country of São Paulo. The application was done collectively, with duration of approximately 40 minutes in one session in the classrooms. According to demand and access, some applications occurred individually in private establishments. After explaining the research objectives and agreement of the participants by signing the consent form, the instruments were applied, seeking to switch the sequence of it presentation.

With the data collection finished, we insert the data into a spreadsheet and proceeded to statistical analyzes. According to the objectives of this study, in a first moment, we compute the number of factors to be kept in the exploratory factor analysis through the parallel analysis (Hayton, Allen, \& Scarpello, 2004; Watkins, 2006). For placement of the analysis, we have used the R software version 2.15.3, since it allows the procedure of parallel analysis for polychoric variables, as is the case in the present study.

In sequence, we generated a database for the software Mplus version 6.12 in order to carry out the exploratory factor analysis with polychoric variables, besides getting fit indices that indicate the suitability of the structure found based on this sample. It is noteworthy also that the adjustment in fit indices also suggests the suitability of the sample for analysis. Finally, we executed correlation analyzes between the factors extracted to the Eccentricity dimension, the factors and facets of the NEO-PI-R, the facets of PID- 5 and total score of the MIS. Furthermore, we generated a profile for four individuals who reached MIS cut-off.

\section{Results}

The Step 1, focused on developing new items for the Eccentricity dimension of IDCP, resulted in 652 new items related to 75 sentences listed as relevant for the dimension. The constructs extracted from the 
literature and highlighted as applicable to Eccentricity dimension were Eccentricity, Identity Confusion, Selfreference, Lack of Empathy, Avoidance of Intimacy, Perceptual and Cognitive Dysregulation, Unusual Beliefs and Experiences, Distrust (APA, 2013); Eccentricity, Avoidance of intimacy, Perceptual Disruption, Beliefs and unusual experiences (Krueger et al., 2012); Thought Disorder, Schizoid Guidance (Shedler \& Westen, 2004); and Eccentric Thought, Distrust, Emotional Coldness, Negative Affect, Anhedonia and Social Isolation (Clark, 1990).

Following the creation of the new items, we set out for analysis and selection of the best items, in independent pairs. The pre-selection resulted in a set of 96 items and was based on criteria such as clarity and consistency in writing, targeting pathological characteristics and relevant traits not well represented in the original IDCP. For selection of the final composite items, we emphasize as our priority criterion the inclusion of items that was not well represented in the original version, which generate the exclusion of 54 items. Thus, the new version of the Eccentricity dimension to be psychometrically tested was composed of 42 items, being 20 from the original version of IDCP and 22 new, grouped into five categories created by the authors, Eccentric style (8 original +2 new), Perceptual dysfunction ( 2 original +7 new), Paranoid ideation ( 2 original +2 new), Magical thinking ( 2 original +6 new), and Offishness ( 6 original +5 new).

In sequence, we investigated the psychometric properties of the 42 items set, starting from the parallel analysis for polychoric variables determining the maximum number of factors for the reviewed scale. We obtained six factors as maximum, with significant eigenvalues not randomly established. Thus, we proceeded to the exploratory factor analysis with fit indices (E-SEM), forcing solutions of two to six factors using the Geomin oblique rotation and using the extraction method Maximum Likelihood Robust (MLR), considered as a robust method suitable for polychoric variables.

We evaluated the indices for the models and identified the six and five factors as the best fits models, respectively. The focus was given to these models and the factors interpretability was verified. The model with six factors showed the best interpretability, since the last factor of the five factors model was not interpretable at all. Based on this and on the similarity of fit indices of these two solutions, we chose the solution composed of six factors. The fit index obtained were
$\mathrm{X}^{2} / d f=2.27$ (acceptable); RMSEA $=.077$ (acceptable); CFI $=.70$ (unsatisfactory); and SMR = .046 (good), based on Hooper, Coughlan and Mullen (2008) for index criteria. The Table 1 shows the factors loadings, the number of items held by factor and internal consistency (Cronbach's alpha). The items that remained in each of the factors are bolded.

The final version of the reviewed dimension is

Table 1. Exploratory Factor Analysis and Internal Consistency for the IDCP Eccentricity Dimension.

\begin{tabular}{|c|c|c|c|c|c|c|}
\hline & I.D. & E.S. & Paran. & Persec. & Desp. & E.I. \\
\hline A028 & 0.64 & 0.21 & 0.24 & 0.14 & 0.30 & 0.18 \\
\hline A031 & 0.65 & 0.38 & 0.22 & 0.28 & 0.35 & 0.13 \\
\hline A032 & 0.37 & 0.39 & 0.73 & 0.39 & 0.31 & 0.11 \\
\hline A082 & 0.25 & 0.71 & 0.18 & 0.28 & 0.24 & 0.16 \\
\hline B137 & 0.38 & 0.31 & 0.27 & 0.76 & 0.04 & 0.11 \\
\hline B138 & 0.22 & 0.23 & 0.78 & 0.28 & 0.26 & 0.24 \\
\hline B190 & 0.24 & 0.78 & 0.29 & 0.44 & 0.26 & 0.29 \\
\hline B191 & 0.28 & 0.81 & 0.13 & 0.32 & 0.10 & 0.28 \\
\hline B193 & 0.62 & 0.28 & 0.22 & 0.24 & 0.34 & 0.26 \\
\hline 1625 & 0.29 & 0.53 & 0.27 & 0.35 & 0.65 & 0.23 \\
\hline 1626 & 0.18 & 0.19 & 0.22 & 0.22 & 0.56 & 0.19 \\
\hline 1627 & 0.25 & 0.36 & 0.13 & 0.17 & 0.69 & 0.21 \\
\hline 1629 & 0.33 & 0.34 & 0.13 & 0.64 & 0.44 & 0.11 \\
\hline 1630 & 0.26 & 0.33 & 0.33 & 0.73 & 0.38 & 0.14 \\
\hline 1634 & 0.17 & 0.26 & 0.62 & 0.26 & 0.11 & -0.04 \\
\hline 1637 & 0.34 & 0.16 & 0.08 & 0.10 & 0.21 & 0.46 \\
\hline 1638 & 0.21 & 0.28 & 0.10 & 0.24 & 0.19 & 0.60 \\
\hline 1639 & 0.22 & 0.37 & 0.09 & 0.14 & 0.23 & 0.69 \\
\hline Initial $\mathrm{N}$ items & 8 & 9 & 6 & 6 & 5 & 3 \\
\hline Final $\mathrm{N}$ items & 3 & 3 & 3 & 3 & 3 & 3 \\
\hline Initial alpha & .77 & .84 & .80 & .79 & .74 & .60 \\
\hline Final alpha & .70 & .82 & .74 & .74 & .69 & .60 \\
\hline
\end{tabular}

I.D.: Interpersonal detachment; E.S.: Eccentric style; Paran.: Paranormality; Persec.: Persecutoriety; Desp.: Depersonalization; E.I.: Emotional inexpressiveness Items starting with letters $\mathrm{A}$ or $\mathrm{B}$ refers to the original version and starting with I, to new items.

composed of 18 items, nine (50\%) been new, distributed into six factors with three items each. We sought to explicitly maintain a minimum number of items per factor, since the IDCP is composed of 12 dimensions and the test administration would be extensive and exhaustive to patients with clinical issues. Therefore, we discarded some items with suitable properties. In short, we used four criteria for exclusion of items, (a) the item prejudice or not favour the internal consistency of the factor, (b) little interpretative consistency to remain 
the item, (c) significant loads on more than one factor (difference less than .50 in intrafactors loads), and (d) content redundancy among items in the same factor.

Internal consistency was equal or higher than .70 in four factors, and less than that in two cases. The coefficient for the total score was .85. It's important to consider the number of items in the interpretation of the internal consistency. For example, using the Spearman-Brown prophecy formula $\left(\frac{n * r}{1+(n-1) r}\right.$; where $\mathrm{n}$ is the number of items and $r$ is the actual reliability) in an application as done by Hirai (1999), we could find the factor 6 showing .90 instead .60 of internal consistency (considering more three items with the same intracorrelation as the actual three items). After defining the internal structure of the instrument, we conduced analyses to correlate the factors and total score with the factors and facets of the NEO-PI-R, PID-5 and MIS. Table 2 shows the results of the correlations between the factors and the total score of the new Eccentricity dimension and both dimensions of the NEO-PI-R.

The correlations between factors of the revised dimension varied from .15 to .44 , and between the factors and the total score (revised) from .58 to .71. The same table also shows the correlations between the new Eccentricity factors and two factors of the NEO-PI-R. Specifically regarding to Neuroticism, the correlations were greater with Interpersonal detachment and lower with Paranormal. The correlations found for Agreeableness, unlike the correlations with Neuroticism, tended to be negative, and the greater correlation was with Persecutoriety and the smaller with Eccentric style and Paranormality. The total score for the original dimension was also calculated, and the magnitudes of correlation were similar for total score revised. In sequence, Table 3 shows the correlations with the facets of Neuroticism and Agreeableness.

In a broad perspective, the correlation between facets of Neuroticism and Agreeableness from NEO-PI-R with Eccentricity factors tended to be lower than the correlations with the facets of PID-5 and total score from MIS. Beside this, it appears that the total scores of the scale of IDCP, original and revised, were similar in most cases. Specifically considering the facets of Neuroticism, Paranormality showed the lower correlations and the Depression facet was the one to present the largest number of most expressive correlations. In regard to Agreeableness, the highest correlations were between Trust facet and Interpersonal detachment and Persecutoriety factors. Still, the factor Persecutoriety showed the most expressive negative correlations with the facets of Agreeableness.

Related to PID-5, the Eccentricity facet showed the highest correlation with Eccentric style factor; Intimacy Avoidance with Emotional inexpressiveness, Interpersonal detachment and Despersonalization; the facet Perception Dysregulation showed higher correlations with Despersonalization, Paranormality and Eccentric style; and the facet Unusual Beliefs \& Experiences with Paranormality factor. For the MIS, the strongest correlation was with the Paranormality factor. In addition, we pointed out that the new total score showed more correlation with Eccentricity and Perceptual Dysregulation of PID-5. As the final analysis to be presented, we calculated the profile for the four people who reached the MIS cut-off against the people who does not (Figure 1).

Table 2. Correlations Between Factors and Total Score of the New IDCP Eccentricity Dimension and NEO-PI-R Dimensions.

\begin{tabular}{lcccccccc}
\hline & I.D. & E.S. & Paran. & Persec. & Desp. & E.I. & N.E.T.S. & O.E.T.S. \\
\hline I.D. & 1 & $0.32^{* *}$ & $0.35^{* *}$ & $0.36^{* *}$ & $0.37^{* *}$ & $0.32^{* *}$ & $0.69^{* *}$ & $0.74^{* *}$ \\
E.P. & $0.32^{* *}$ & 1 & $0.38^{* *}$ & $0.39^{* *}$ & $0.44^{* *}$ & $0.34^{* *}$ & $0.71^{* *}$ & $0.67^{* *}$ \\
Paran. & $0.35^{* *}$ & $0.38^{* *}$ & 1 & $0.42^{* *}$ & $0.39^{* *}$ & $0.15^{*}$ & $0.66^{* *}$ & $0.60^{* *}$ \\
Persec. & $0.36^{* *}$ & $0.39^{* *}$ & $0.42^{* *}$ & 1 & $0.39^{* *}$ & $0.21^{* *}$ & $0.70^{* *}$ & $0.68^{* *}$ \\
Desp. & $0.37^{* *}$ & $0.44^{* *}$ & $0.39^{* *}$ & $0.39^{* *}$ & 1 & $0.33^{* *}$ & $0.69^{* *}$ & $0.50^{* *}$ \\
E.I. & $0.32^{* *}$ & $0.34^{* *}$ & $0.15^{*}$ & $0.21^{* *}$ & $0.33^{* *}$ & 1 & $0.58^{* *}$ & $0.44^{* *}$ \\
N.E.T.S. & $0.69^{* *}$ & $0.71^{* *}$ & $0.66^{* *}$ & $0.70^{* *}$ & $0.69^{* *}$ & $0.58^{* *}$ & 1 & $0.91^{* *}$ \\
O.E.T.S. & $0.74^{* *}$ & $0.67^{* *}$ & $0.59^{* *}$ & $0.68^{* *}$ & $0.50^{* *}$ & $0.44^{* *}$ & $0.91^{* *}$ & 1 \\
N & $0.31^{* *}$ & $0.29^{* *}$ & 0.13 & $0.24^{* *}$ & $0.22^{* *}$ & $0.21^{* *}$ & $0.33^{* *}$ & $0.41^{* *}$ \\
A & $-0.24^{* *}$ & $-0.18^{* *}$ & $-0.14^{*}$ & $-0.33^{* *}$ & $-0.24^{* *}$ & $-0.14^{*}$ & $-0.31^{* *}$ & $-0.34^{* *}$ \\
\hline
\end{tabular}

${ }^{*}$ significant magnitude level $p \leq 0.05 ;{ }^{* *}$ significant magnitude level $p \leq 0.01$. I.D.: Interpersonal detachment; E.S.: Eccentric style; Paran.: Paranormality; Persec.: Persecutoriety; Desp.: Depersonalization; E.I.: Emotional inexpressiveness; N: Neuroticism; A: Agreeableness; N.E.T.S.: New Eccentricity total score; O.E.T.S.: Original Eccentricity total score. 
L. F. Carvalho, G. Pianowski, F. J. Silveira, J. T. Bacciotti, P. G. Vieira

Table 3. Correlations Between IDCP Eccentricity Dimension and NEO-PI-R, PID-5 and MIS.

\begin{tabular}{|c|c|c|c|c|c|c|c|c|c|}
\hline & & I.D. & E.S. & Paran. & Persec. & Desp. & E.I. & N.E.T.S. & O.E.T.S. \\
\hline \multirow{6}{*}{ 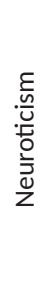 } & Anxiety & 0.13 & $0.29^{* *}$ & 0.04 & $0.22^{* *}$ & $0.19^{* *}$ & $0.17^{*}$ & $0.25^{* *}$ & $0.26^{* *}$ \\
\hline & Anger/Hostility & $0.25^{* *}$ & $0.19^{* *}$ & $0.14^{*}$ & $0.24^{* *}$ & $0.14^{*}$ & 0.06 & $0.23^{* *}$ & $0.38^{* *}$ \\
\hline & Depression & $0.39 * *$ & $0.27^{* *}$ & $0.13^{*}$ & $0.23^{* *}$ & $0.27^{* *}$ & $0.26^{* *}$ & $0.37^{* *}$ & $0.44^{* *}$ \\
\hline & Embarrassment/Constraint & $0.27^{* *}$ & $0.18^{* *}$ & 0.02 & 0.07 & $0.14^{*}$ & $0.23^{* *}$ & $0.28^{* *}$ & $0.29 * *$ \\
\hline & Impulsivity & 0.09 & $0.28^{* *}$ & $0.15^{*}$ & $0.14^{*}$ & $0.13^{*}$ & 0.11 & $0.20^{* *}$ & $0.27^{* *}$ \\
\hline & Vulnerability & $0.23^{* *}$ & 0.20 & 0.06 & $0.14^{*}$ & 0.10 & 0.12 & $0.21^{* *}$ & $0.25^{* *}$ \\
\hline \multirow{6}{*}{ 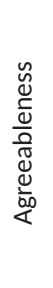 } & Trust & $-0.35^{* *}$ & $-0.15^{*}$ & $-0.15^{*}$ & $-0.29^{* *}$ & $-0.25^{* *}$ & $-0.19^{*}$ & $-0.31^{* *}$ & $-0.35^{* *}$ \\
\hline & Frankness & -0.06 & $-0.19^{* *}$ & -0.09 & $-0.20^{* *}$ & $-0.26^{* *}$ & $-0.16^{*}$ & -0.06 & $-0.19^{* *}$ \\
\hline & Altruism & $-0.26^{* *}$ & $-0.16^{*}$ & -0.08 & $-0.21^{* *}$ & $-0.16^{*}$ & $-0.14^{*}$ & $-0.25^{* *}$ & $-0.32^{* *}$ \\
\hline & Complacency & -0.07 & $-0.16^{*}$ & -0.09 & $-0.23^{* *}$ & -0.12 & -0.09 & $-0.17^{*}$ & $-0.18^{* *}$ \\
\hline & Modesty & -0.05 & -0.05 & -0.09 & $-0.23^{* *}$ & 0.02 & 0.02 & $-0.13^{*}$ & $-0.15^{*}$ \\
\hline & Sensitivity & -0.12 & 0.01 & -0.05 & -0.11 & $-0.14^{*}$ & -0.03 & -0.09 & -0.10 \\
\hline \multirow{4}{*}{ ํㅜ } & Eccentricity & $0.45^{* *}$ & $0.70^{* *}$ & $0.47^{* *}$ & $0.41^{* *}$ & $0.56^{* *}$ & $0.49^{* *}$ & $0.75^{* *}$ & $0.67^{* *}$ \\
\hline & Intimacy Avoidance & $0.31^{* *}$ & $0.21^{* *}$ & $0.14^{*}$ & $0.19^{* *}$ & $0.37^{* *}$ & $0.57^{* *}$ & $0.42^{* *}$ & $0.38^{* *}$ \\
\hline & Perception Dysregulation & $0.41^{* *}$ & $0.48^{* *}$ & $0.49^{* *}$ & $0.41^{* *}$ & $0.65^{* *}$ & $0.35^{* *}$ & $0.67^{* *}$ & $0.59^{* *}$ \\
\hline & Unusual Beliefs \& Experiences & $0.37^{* *}$ & $0.38^{* *}$ & $0.64^{* *}$ & $0.44^{* *}$ & $0.32 * *$ & $0.21^{* *}$ & $0.59^{* *}$ & $0.59^{* *}$ \\
\hline$\stackrel{\varrho}{\Sigma}$ & Total score & $0.30^{* *}$ & $0.26^{* *}$ & $0.45^{* *}$ & $0.36^{* *}$ & $0.27^{* *}$ & $0.15^{*}$ & $0.45^{* *}$ & $0.45^{* *}$ \\
\hline
\end{tabular}

${ }^{*}$ significant magnitude level $p \leq 0.05 ;{ }^{* *}$ significant magnitude level $p \leq 0.01$. I.D.: Interpersonal detachment; E.S.: Eccentric style; Paran.: Paranormal; Persec.: Persecutoriety; Desp.: Depersonalization; E.I.: Emotional inexpressiveness; N.E.T.S.: New Eccentricity total score; O.E.T.S.: Original Eccentricity total score.

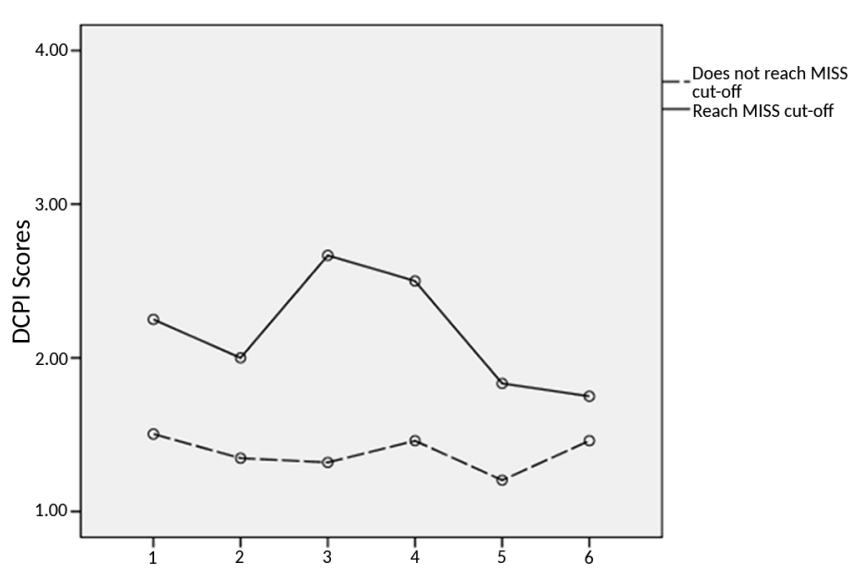

Figure 1. Profiles in IDCP Eccentricity Factors Based on MIS Scores. 1: Interpersonal detachment; 2: Eccentric style; 3: Paranormal; 4: Persecutoriety; 5: Depersonalization; 6: Emotional inexpressiveness.

As can be viewed, the profile of people who reached is more intense in the Eccentricity factors. Moreover, this group showed an expressive elevation in the Paranormality factor which does not happened in the other group; in contrast, the group that not reached the cut-off showed an elevation in the Emotional inexpressiveness that not occurred with the other group.

\section{Discussion}

In the first step of the review, the items were grouped in categories, as Eccentric style (unusual habits and behaviours, uncommon by people around), Perceptual dysfunction (regarded to a dysfunction in distinguish reality accurately, sometimes sensing it as unreal or mixed with imagination), Paranoid ideation (items associated to the idea of having been focus of conspiracy and teasing by others), Magical thinking (including the belief in hidden meanings in the everyday situations and unnatural experiences) and Offishness (comprising the distance and lower interest in relationships). The selection of new items to be empirically tested was made by the judges (i.e., authors of this work), regarding the content, redundancy and appropriateness of writing, which was aimed to improving the dimension with the inclusion of new items.

A set of 42 items was selected and applied to be psychometrically analyzed. As the six-factor solution was the most appropriate model, we moved on to selecting the best items, which resulted in 18 items composing the dimension. We observed similarity between the original version (original Eccentricity total score - OETS) and the new Eccentricity dimension (new Eccentricity 
total score - NETS) in the correlations with other tests, demonstrating that both reach comparable levels in the construct, focused on pathological manifestation; however, the inclusion of nine new items psychometrically selected increased the scope and representation of the construct in the dimension. It is noteworthy that the data found by Carvalho and Primi (2015) did not indicate need for development of more pathological items for the Eccentricity dimension, unlike other dimensions (i.e., Carvalho, Sette, Capitão et al., 2014; Carvalho, Souza et al., 2014a).

The Eccentricity six factors include characteristics such as detachment, maladjustment and disinterest in interpersonal relationships found in the Interpersonal detachment factor (ID); style perceived by others as strange (Eccentric style; ES); experiences and supernatural beliefs in Paranormality factor (Paran.); feeling and idea that has been the target of plots or has been monitored by third parties, included in Persecutoriety (Persec.); distancing from reality, including feelings of unreality and confusion of identity (Depersonalization; Desp.); and downgrade in the experience and expression of emotions, encompassed in factor Emotional inexpressiveness (EI). About dimension coverage, the review included content such as paranoid, depersonalization and emotional inexpressiveness, not well represented in the original version (Carvalho \& Primi, 2015) and that are valuable in the assessment of the personality disorders related, schizotypal and schizoid (APA, 2013; Hopwood et al., 2012; Samuel et al., 2012). Moreover, the scale had a moderate, not higher, correlation between its factors, which is an important indicator of the possibility of Eccentricity profiles, which should be investigated in future studies.

Regarding the psychometric quality of the new dimension, we perceived adequate internal consistency coefficients for the total score and four factors (Embretson, 1996; Nunnally, 1978). However, the Depersonalization and Emotional inexpressiveness factors showed values lower than .70 (adequate according to Embretson, 1996; Nunnally, 1978), being .69 and .60, respectively. Considering the small number of items (i.e., three), this value lies not short of expectations, which can be further legitimized by the results observed when using the Spearman-Brown formula prophecy that predicts internal consistency of approximately. 90 to both factors if a greater number of items (i.e., twice) were used. In this sense, the reduction of items was prioritized to enable a non-exhaustive application, benefiting the clinical use of the inventory.
Relative to correlation with NEO-PI-R dimensions (Costa Jr. \& McCrae, 2009), an important issue is the absence of dimensions and facets corresponding to the content considered encompassed by the Eccentricity dimension, which reduces the possibility of high magnitudes of correlation. Moreover, unlike the IDCP, PID-5 and MIS, the NEO-PI-R was developed for assessment of healthy personality traits (despite Neuroticism encompasses less adaptive ways, it was not designed to access necessarily pathological levels of the constructs), which should also have an impact on the effect size of the correlations. Among the Neuroticism facets, Depressivity seems more correlated to the Eccentricity, despite lower effect sizes. As Agreeableness, the correlations showed a trend opposite to what is measured by the Eccentricity dimension. This result is consistent, for example, considering the contradiction between Trust (tendency to believe that others are honest and well intentioned) and Altruism (active concern for the welfare of others) facets of the NEO-PI-R, and Persecutoriety and Interpersonal detachment factors of the IDCP.

In contrast, the correlations between Eccentricity factors and PID-5 facets and MIS total score were more expressive, which should be related to the fact that these tests were also developed to targeting pathological levels, as the IDCP. Regarding the PID-5, we observed that this has more facets associated with content encompassed by the IDCP reviewed dimension associated with the habits, unusual beliefs and experiences, even supernatural, drawdown in interest, interpersonal approach and perceptual distinctions in facets such as Eccentricity, Intimacy Avoidance, Perception Dysregulation, Unusual Beliefs \& Experiences (Krueger et al., 2012). This can be clearly seen in the high correlation between PID-5 Eccentricity facet and IDCP Eccentric style factor ( $r=$ .70), and PID-5 Perception Dysregulation facet and IDCP Depersonalization factor $(r=.65)$. These data also suggest the appropriateness of the reviewed dimension in the assessment of pathological levels of the construct. Still, these features encompassed by IDCP Eccentricity dimension are being considered relevant (Abela et al., 2015; Carvalho \& Primi, 2015) to schizotypal and schizoid personality disorder (APA, 2013; Hopwood et al., 2012; Samuel et al., 2012).

Finally, the Paranormal factor from IDCP Eccentricity showed the highest correlation with the total score from MIS $(r=.45)$, which is coherent, since this IDCP factor embraces the experience and belief in the supernatural and the MIS consist in a scale which specifically assesses the magic thought related to the schizophrenic 
spectrum (Chapman et al., 1994; Eckblad \& Chapman, 1983). Complementary, the data found in the Figure 1 , i.e., distribution of scores from two select groups based on the MIS score, revealed that the group with the highest scores in MIS had higher scores on Paranormal factor. This data is also an important indicator of the suitability of establishing sub-profiles for Eccentricity dimension of IDCP. Considering the nonclinical priority nature of the sample, the MIS pathological content related to supernatural experiences may have hindered the sample identification with it items. A moderate correlation between MIS and Paranormal instigates the need for verification of this correlation in clinical groups, which applies for the other instruments (i.e., NEO-PI-R and PID-5) as well.

\section{Conclusion}

The data presented in this study demonstrated that the review of Eccentricity dimension of IDCP achieved good results to its clinic use, by presenting a broader dimension as the representativeness of the construct. Added to this, the results showed evidence of validity based on internal structure and in relation with external variables. We emphasize the importance of replication of the structure in future studies, and of the verification of the reliability indexes based on the levels of the participants in the latent construct, for example, using local reliability (Daniel, 1999). Also the use of other mathematical models, as Item Theory Response (IRT) would possibility the comparison at the item level between the original and the revised Eccentricity dimension. As a limitation of the study we highlight the characteristic of the sample, not including clinical group; we also point out to the use of judges, which in the present study were all coauthors from the paper. The extending of investigations in clinical groups, with primacy of patients with personality disorders, will improve the applicability of the IDCP.

\section{References}

Abela, R. K., Carvalho, L. F., Cho, S. J. M., \& Yazigi, L. (2015). Validity evidences for the Dimensional Clinical Personality Inventory in Outpatient Psychiatric Sample. Paidéia; 25, 221-28. doi: 10.1590/1982-43272561201510

American Psychiatry Association (2013a). DSM-5: diagnostic and statistical manual of mental disorders 5. Washington: American Psychiatry Association.

American Psychiatry Association (2003b). DSM IV-TR: diagnostic and statistical manual of mental disorders (4th ed. revised). Washington: American Psychiatry Association.
Carvalho, L. F., \& Arruda, W. (2016). Revisão da dimensão isolamento do Inventário Dimensional Clínico da Personalidade. Temas em Psicologia, 24(1), 47-61. doi: 10.9788/TP2016.1-04.

Carvalho, L. F., Oliveira Filho, A. Q., Pessotto, F., \& Bortolotti, S. L. V. (2014) Application of the unfolding model to the aggression dimension of the Dimensional Clinical Personality Inventory (DCPI). Revista Colombiana de Psicologia, 23(2), 339-49. doi: 10.15446/rcp.v23n2.41428

Carvalho, L. F., \& Pianowski, G. (2015). Revision of the dependency dimension of the Dimensional Clinical Personality Inventory. Paidéia, 25(60), 57-65. doi: 10.1590/1982-43272560201508

Carvalho, L. F., Pianowski, G., \& Miguel, F. K. (2015). Revision of the aggressiveness dimension of Dimensional Clinical Personality Inventory. Revista Psicologia-Teoria e Prática, 17(3), 146-163. doi: 10.15348/1980-6906/psicologia.v17n3p146-163

Carvalho, L. F., \& Primi, R. (2015). Development and internal structure investigation of the Dimensional Clinical Personality Inventory (IDCP). Psicologia: Reflexão e Crítica, 28(2), 322-330. doi: 10.1590/16787153.201528212

Carvalho, L. F., \& Primi, R (2016). Prototype matching of personality disorders with the Dimensional Clinical Personality Inventory. Psicologia: Teoria e Pesquisa, 32(2), 1-9. doi: 10.1590/0102-3772e322214.

Carvalho, L. F., Primi, R., \& Stone, G. E. (2014). Psychometric properties of the Inventário Dimensional Clínico da Personalidade (IDCP) using the Rating Scale Model. Avances em Psicología Latinoamericana, 32(3), 433-46. doi: 10.12804/apl32.03.2014.09.

Carvalho, L. F., \& Sette, C. P. (in press). Criticism avoidance dimension of the Dimensional Clinical Personality Inventory revision. Estudos de Psicologia (PUCCAMP).

Carvalho, L. F., \& Sette, C. P. (2015). Review and verification of the psychometric properties of the mood instability dimension of the Dimensional Clinical Personality Inventory. Acta Colombiana de Psicología, 18(2), 115-127. doi: 10.14718/ACP.2015.18.2.10

Carvalho, L.F., Sette, C. P., \& Capitão, C. G. (2016). Investigation of the clinical functioning of the Attention Seeking Dimensional Clinical Personality Inventory. Psicologia, 30(1), 49-60. doi: 10.17575/rpsicol.v30i1.1072.

Carvalho, L. F., Sette, C. P., Capitão, C. G., \& Primi, R. (2014). Propriedades psicométricas da versão revisada da dimensão necessidade de atenção do inventário dimensional clínico da personalidade. Temas em Psicologia, 22(1), 147-60. doi: 10.9788/TP2014.1-12

Carvalho, L. F., Sette, C. P., \& Ferrari, B. L. (2016). Revision of the grandiosity dimension of the Dimensional Clinical Personality Inventory and verification of its psychometric properties. Trends in Psychiatry and Psychotherapy, 38(3), 1-9. doi: 10.1590/2237-6089-2015-0040

Carvalho, L. F., \& Silva, G. F. C. (2016). Review of the self-sacrifice dimension of the Dimensional Clinical Personality Inventory. Psicologia: Reflexão e Crítica, 29(6), 1-8. doi: 10.1186/s41155-016-0022-z

Carvalho, L. F., Souza, B. D. B., \& Primi, R. (2014a). Psychometric properties of the revised conscientiousness dimension of Inventário Dimensional Clínico da Personalidade (IDCP). Trends in Psychiatry and Psychotherapy, 36(1), 23-31. doi: 10.1590/2237-6089-2013-0024

Carvalho, L. F., Souza, B. D. B., \& Primi, R. (2014b). Revisão da Dimensão Conscienciosidade do Inventário Dimensional Clínico da Personalidade. CES Revista Psicologia, 7(2), 1-14. Recuperado de http://revistas.ces.edu.co/index.php/psicologia/article/view/2676

Chapman, L. J., Chapman, J. P., Kwapil, T. R., Eckblad, M., \& Zinser, M. C. (1994). Putatively psychosis-prone subjects 10 years later. Journal of Abnormal Psychology, 103, 171-183. doi: 10.1037/0021843X.103.2.171 
Clark, L. A. (1990). Toward a consensual set of symptom clusters for assessment of personality disorder. In J. N. Butcher \& C. D. Spielberger (Eds.), Advances in personality assessment (Vol. 8, pp. 243-266). Hillsdale, NJ: Lawrence Erlbaum.

Costa Jr., P. T., \& McCrae, R. (2009). NEO-PI-R - Inventário de Personalidade NEO Revisado - Manual. São Paulo: Vetor.

Daniel, M. H. (1999). Behind the scenes: using new measurement methods on the DAS and KAIT. In S. E. Embretson \& S. L. Hershberger (Eds.), The new rules of measurement: what every psychologist and educator should know (pp. 37-63). Lawrence Erlbaum Associates, New Jersey.

Eckblad, M., \& Chapman, L. J. (1983). Magical ideation as an indicator of schizotypy. Journal of Consulting \& Clinical Psychology, 51, 215225. doi: 10.1037/0022-006X.51.2.215

Embretson, S. E. (1996). The new rules of measurement. Psychological Assessment, 8(4), 341-349. doi: 10.1037/1040-3590.8.4.341

Hayton, J. C., Allen, D. G., \& Scarpello, V. (2004). Factor retention decisions in exploratory factor analysis: a tutorial on parallel analysis. Organizational Research Methods, 7(2), 191-205. doi: 10.1177/1094428104263675

Hirai, A. (1999). The relationship between listening and reading rates of Japanese EFL learners. Modern Language Journal, 83, 367-384. doi: 10.1111/0026-7902.00028

Hooper, D., Coughlan, J., \& Mullen, M. R. (2008). Structural equation modelling: guidelines for determining model fit. The Electronic Journal of Business Research Methods, 6(1), 53-60.

Hopwood, C. J., Thomas, K. M., Markon, K. E. Wright, A. G. C., \& Krueger, R. F. (2012). DSM-5 Personality Traits and DSM-IV Personality Disorders. Journal of Abnormal Psychology, 121(2), 424-432. doi: $10.1037 / \mathrm{a} 0026656$
Krueger, R. F., Derringer, J., Markon, K. E., Watson, D., \& Skodol, A. E. (2012). Initial construction of a maladaptive personality trait model and inventory for DSM-5. Psychological Medicine, 42(9), 1879-1890. doi: $10.1017 /$ S0033291711002674

Millon, T., \& Grossman, S. (2007a). Moderating severe personality disorders. New Jersey: John Wiley \& Sons Inc.

Millon, T., \& Grossman, S. (2007b). Overcoming resistant personality disorders. New Jersey: John Wiley \& Sons Inc.

Millon, T., Grossman, S., \& Tringone, R. (2010). The Millon Personality Spectrometer: a tool for personality spectrum analyses, diagnoses, and treatments. In T. Millon, R. F. Krueger, \& E. Simonsen (Eds.), Contemporary directions in psychopathology: scientific foundations of the DSM-V and ICD-11 (pp. 391-418). New York: The Guilford Press.

Millon, T, Millon, C. M., Meagher, S., Grossman, S., \& Ramanath, R. (2004). Personality disorders in modern life. New Jersey: Wiley.

Nunnally, J. C. (1978). Psychometric theory. New York: McGraw-Hill.

Samuel, D. B., Lynam, D. R., Widiger, T. A., \& Ball, S. A. (2012). An expert consensus approach to relating the Pproposed DSM-5 types and traits. Personality Disorders: Theory, Research, and Treatment, 3(1), 1-16. doi: 10.1037/a0023787

Shedler, J., \& Westen, D. (2004). Dimensions of personality pathology: an alternative to the five factor model. American Journal of Psychiatry, 161(10), 1743-1754. doi: 10.1176/appi.ajp.161.10.1743

Vieira, P. G., Villemor-Amaral, A. E., \& Pianowski, G. (in press). Tradução, adaptação e evidências iniciais de validade da Magical Ideation Scale. Psicologia: Teoria e Pesquisa (UnB. Impresso).

Watkins, M. W. (2006). Determining parallel analysis criteria. Journal of Modern Applied Statistical Methods, 5(2), 344-346. Retrieved from http://digitalcommons. wayne.edu/jmasm/vol5/iss2/8

Lucas de Francisco Carvalho, Doutor em Psicologia com ênfase em Avaliação Psicológica pela Universidade São Francisco (USF), é Docente do Programa de Pós-Graduação Stricto Sensu em Psicologia da Universidade São Francisco (USF). Endereço para correspondência: Universidade São Francisco. Av. Senador Lacerda

Franco, 360, Centro - Itatiba-SP CEP 13251-900. E-mail: lucas@labape.com.br

Giselle Pianowski, Mestre em Psicologia com ênfase em Avaliação Psicológica pela Universidade São Francisco (USF), é Doutoranda do Programa de Pós-Graduação Stricto Sensu em Psicologia da Universidade São Francisco (USF). E-mail: gisellepianowski@gmail.com

Fernando José Silveira, Doutor em Psicologia com ênfase em Avaliação Psicológica pela Universidade São Francisco (USF), é Docente na Universidade do Vale do Sapucaí (UNIVAS) e no Instituto de Pós-Graduação de Goiás (IPOG). E-mail: silveirafjs@gmail.com

Jonatha Tiago Bacciotti, Mestre em Psicologia com ênfase em Avaliação Psicológica pela

Universidade São Francisco (USF), é Doutorando do Programa de Pós-Graduação Stricto Sensu em Psicologia da Universidade São Francisco (USF). E-mail: johbacciotti@gmail.com

Philipe Gomes Vieira, Mestre e Doutorando em Psicologia com ênfase em Avaliação Psicológica pela Universidade São Francisco (USF), é Professor do Instituto de Pós-Graduação de Goiás (IPOG). E-mail: philipevieira@ymail.com

Recebido em 05.Fev.15

Revisado em 19.Jul.16

Aceito em 16.Nov.16 